\title{
SOVEREIGNTY AND THE MOTION TO IMPEACH BRAZIL'S PRESIDENT
}

Vania Siciliano Aieta

Post-Doctoral Researceher by PUC RJ. PhD and Master by PUC SP. Professor of Universidade do Estado do Rio de Janeiro, Brazil.

vaniaaieta@siqueiracastro.com

Ricardo Lodi

$\mathrm{PhD}$ by Universidade Gama Filho. Professor at Universidade do Estado do Rio de Janeiro, Brazil.

rlodi@bfbm.com.br

Received: 2016-04-23 - Accepted: 2016-07-11.

\begin{abstract}
This article aims to demonstrate that public policies involving the economy follow, in their process of formulation, implementation and especially results, different paths than those for the exercise of political power.

This involves a question of decisions. The decisions of public officials and even of judges are not aseptic, but instead ideological.

Economic crises and political disaffections over these choices cannot serve as justifications for removing that leader, elected by popular vote, especially when the "rules of the political game", have all been respected.

When democracy is threatened by such incidents, motivated by an economic downturn, notably in supposed exceptions that in reality flaunt the constitutional and legal order, we are faced with a serious injury to sovereignty in the internal plane, perhaps even a coup d'état. This article will analyze the question of the motion to impeach Brazil's president, demonstrating there is no legal support because she has not committed any act of malfeasance in office. And we conclude that in name of seeking more successful economic results, to serve political demands that are most of the time instigated by ideological passions, a society cannot ride roughshod over fundamental rights assured by the Constitution.
\end{abstract}


Keywords: Impeachment - Due Process of Law - Democracy

\section{The GUARANTEE OF SOVEREIGNTY IN THE INTERNAL PLANCE BY RESPECT FOR THE RULES OF THE POLITICAL GAME IN A DEMOCRACY}

Sovereignty has multiple and controversial meanings. But in its essence, it always involves a question of the justification of political power. For this reason, the gist for understanding sovereignty, to paraphrase the eminent Professor Marcelo Figueiredo, is the idea that "those who hold power always need a political-legal justification to give support to this pretension."

Elected leaders always need de facto power in concert with de jure power for the exercise of their functions. The preoccupation is in the definitive affirmation of authority, establishing the constancy and sedimentation of power.

While external sovereignty consists of the manifestation of the legitimacy of states in the international scenario, in the sense of mutual respect, acceptance and coexistence among nations, in the internal plane the idea of sovereignty rests in the electoral universe, notably the power of imperium, arising from elections - the popular vote - in the sense that the leader is vested democratically with authority, by elections that respect the rules of the game, to impose political decisions within the territory of a determined country.

\section{THE DIFFERENT PUBLIC POLICY AGENDAS AND THE DECISION ELEMENT \\ IN THE GOVERNMENTAL SPHERE. POPULAR DISAFFECTION WITH THE GOVERNMENT AND THE DEMOCRATIC CHALLENGE}

Public policies are sets of programs, actions and activities developed by the government, to impose certain political and programmatic objectives, directly or indirectly, with the participation of public or private entities.

Public policies involve, in their process of formulation and implementation, and particularly in the results sought, the ways to exercise political power through directives, guiding principles, rules and procedures for the relations between the public administration and society.

However, it must be noted that the rules regulate those actions, but does not give them meaning. They delimit the freedom of the leader by the paradigms of the deontic modals of the law (prohibited, obligatory, facultative), but the constitutional foundations of the state

1 FIGUEIREDO, Marcelo. Elementos do Estado. São Paulo: Editora Atlas, 2014, p. 25 
do not substitute the individual will of the leader in the universe of discretion to opt for one hermeneutic vector in detriment to other possibilities, choosing one public policy over another.

This involves the question of the power to decide in the governmental universe. The decisions of elected leaders and even of judges - when called to intervene - will never be aseptic. They are ideological and committed to achieving public policies that are in harmony with the ideological bent of a determined government.

Facing the problem of the economic constitution means facing the scope and the limits of the social state. And the social state is the type of state in which the public authorities are not content only to produce rules, but rather seek to direct their policies so that society reaches the intended goals, to enable materialization of basic conditions for social equality among the various groups, classes and regions of the country.

Since political power implies a social relationship involving many actors, with distinct and even contradictory projects and interests, there is a need for social and institutional mediation so that a minimum of consensus can be forged. This is the only way to legitimize and give efficacy to a determined public policy agenda, because formulating a policy implies establishing who will decide, for what reason, by what means, to achieve what consequences, and for whom.

It is exactly at this moment that governmental political decisions make a difference, because there are distinct ways of viewing public policies, notably when dealing with economic matters, ranging from the liberal, to the social-democratic and the socialist.

Obviously the ideological vectors chosen for governmental initiatives in the areas of economics, health, social security and assistance, questions of infrastructure, labor relations and the type of institutional mediations will reveal the political and economic strategy of a determined government. In the final analysis, public policies are tightly linked to the economic model chosen.

\section{The MOtion to IMPEACH PRESIDENT DILMA ROUSSEFF AND THE} LACK OF ITS LEGAL SUPPORT. THE LEGALITY OF THE SO-CALLED ${ }^{6}$ FISCAL MANEUVERS"

In recent decades Latin America has been the stage for a proliferation of impeachment proceedings. These penal judgments have turned into spectacles in which the desire for democracy has been replaced by the "desire for a trial", based on stimulation of the dichotomy between the "bad guys and the good guys".

2 TIBURI, Márcia. Olho de Vidro: a televisão e o estado de exceção da imagem. Rio de Janeiro: Record, 2011, p.18. 
But with the excuse of punishing the "bad guys", the "good guys' also violate the constitutional and legal order.

The democratic winds that swept away the dictatorships that previously abounded in South America brought a predilection for presidential systems. Under presidentialism, impeachable offenses are limited to specific situations, comprehensively defined in the Constitution.

This character of comprehensiveness in numerus clausus serves the function of guaranteeing a distinction between acts that really violate administrative probity, classified as crimes of malfeasance in office, from political dissatisfaction over "mismanagement" or the political choices under the discretionary power exercised by the leader, whether or not there is a consensus in society.

The guarantee that someone may only be found guilty of a crime when the conduct in question is clearly typified in law has been repeatedly ignored in the political arena by resorting to expansive interpretations about indeterminate legal concepts.

It is hard to control the legitimate exercise of a political process with imputations that disregard the limits of substantive legality. The legal situations for protection of fundamental rights have not been protected, and instead have been excluded from the universe of discretionary decision power, as put by Luigi Ferrajoli.

Likewise, the protection of the democratic principle and the need to respect the rules of the game are being replaced by the abusive exercise of power by "niches" of those who are discontented with legitimately elected governments, relying on political judgment as a method to overturn the majority will.

Promoting impeachment processes that do not respect due legal process and instead are based on scattershot inferences formed unilaterally, without legal support, is tantamount to a coup d'état, to paraphrase the words of Brazilian Supreme Court Justice Marco Aurélio Mello.

The democratic credo requires us to rise above political passions and economic crises and always defend fundamental rights, the democratic order and the Constitution. At this moment, international bodies like the Economic Commission for Latin America and the Caribbean (ECLAC), an important entity of the United Nations, have demonstrated concern over Brazil, calling on society to respect the result of the election so as not to destabilized democracy.

Popular sovereignty, the source of legitimacy in a democracy, is manifested in a constitutional mandate obtained at the polls by the chief executive of Brazil.

This position does not ignore the efforts of the judiciary to pursue and punish the culture of corruption, something that is not unique to Brazil.

Despite all the support to official investigations and the enactment of more severe laws to fight corruption, the executive branch 
in Brazil has become a victim of a relentless and inflammatory media campaign to try to reduce the presidential authority and interrupt the mandate that citizens gave to President Dilma Rousseff at the polls, in a campaign that strictly abided by the rules of the game, again to paraphrase Norberto Bobbio.

The apotheosis of the process of destabilizing democracy that exists today can only be described as an attempt to impose parliamentarianism in Brazil, an option that was rejected by a plebiscite in 1993, established in the Constitution of 1988, so that the rule for presidential system today is an entrenchment clause.

This initiative comes from groups in the Brazilian Congress that, due to absence of sufficient votes or inexistence of leaders with sufficient national support to win elections, are trying to assume power through undemocratic routes that attack the democratic state of law, and can be called as an attempted coup.

\subsection{The contractual default of the federal government to public banks and credit transactions}

The so-called fiscal maneuvers involve the systematic delay in transferring money from the National Treasury to Banco do Brasil, Caixa Econômica Federal and BNDES (National Economic and Social Development Bank) to pay benefits or to fund low-interest loans under social programs, such as Bolsa-Família ("Family Stipend"), Minha Casa Minha Vida ("My Home My Life"), farm credit and unemployment insurance, among others. Since the financial institutions make these payments timely, the delay in transfer from the Treasury generates the contractual obligation of the government to pay interest. This mechanism gives a certain aura of balance to the public accounts in moments of shortage of revenue, and is not a good financial practice. However, it cannot be construed as the impeachable offense of malfeasance in office, as will now be demonstrated.

Those who claim this budgetary trickery is criminal malfeasance allege that it involves a credit transaction between the federal government and federal banks, which is forbidden by Complementary Law $^{3} 101 / 2000$, better known as the Fiscal Responsibility Law ("LRF" in the Portuguese initials). In reality, the motion for impeachment that was accepted by the president of the Chamber of Deputies is based on the premise espoused by a finding issued by the Federal Audit Tribunal $\left(\mathrm{TCU}^{4}\right)$ that recommended rejection of the executive branch's accounts

3 A complementary law (lei complementar) is an enabling law of constitutional provisions.

4 The TCU is an administrative rather than judicial court, entrusted with oversight of budget matters and accounts of all federal government entities, including government controlled companies with private ownership, such as Petrobras and Banco do Brasil. 
for 2014. According to this position, the delay in transferring money from the Treasury to pay social benefits by official banks, so that they had to advance the funds to cover those payouts, caused them to have a credit against the government, something that is forbidden by Article 36 of the LRF, which prohibits lending transactions between government entities and banks controlled by them.

Initially it should be clarified that the rule of Article 36 of the LRF was a response to the abuses of the 1980s and 90s, when state governments bled the banks controlled by them through loan transactions that were never settled and that were above the banks' financial capacities. This wound up causing the liquidation (or fire-sale privatization) of nearly all these institutions. Therefore, to prevent the capital of public sector banks from being drained in this manner, leading to their failure, the Fiscal Responsibility Law prohibits these banks from engaging in credit transactions with the governments that control them. But it is necessary to define what a credit transaction is from a strictly legal standpoint, to prevent other contractual relationships, in the interest of society and official financial institutions, from being barred.

In this respect, Brazil's positive financial law establishes the concept of a credit transaction in cases where the debtor is a publicsector entity, in Article 29, III, of the Fiscal Responsibility Law, in a definition in line with that of Article 3 of Resolution 43/2001 from the Federal Senate, which is empowered by Article 52 of the Constitution to set rules, including limits, on credit transactions contracted by the federal government. ${ }^{5}$

5 Article 29, III, of the LRF reads: "Art. 29. For the effects of this Complementary Law, the following definitions are adopted: III - credit transaction: a financial commitment assumed by reason of a loan, opening of a credit facility, issuance and acceptance of bonds, financed acquisition of goods, advance receipt of amounts from installment sale of goods and services, commercial leasing and other similar transactions, including with use of financial derivatives." In turn, Article 3 of Senate Resolution 43/01 states: "Art. 3. A credit transaction, for the effects of this Resolution, is defined as a financial commitment assumed with creditors located in the country or abroad, by reason of a loan, opening of a credit facility, issuance and acceptance of bonds, financed acquisition of goods, advance receipt of amounts from installment sale of goods and services, commercial leasing and other similar transactions, including with use of financial derivatives. $\S 1$. The following are equated with credit transactions: (Renumbered from the sole paragraph of Resolution 19 of 2003) I - advance receipt of amounts from a company in which the public administration detains, directly or indirectly, the majority of the voting capital, except for profits and dividends, as defined in legislation; II - direct assumption of a commitment, debt confession or similar transaction with a supplier of goods, merchandise or services, by issuance, acceptance or guarantee of credit instruments; III - assumption of an obligation, without budget authorization, with suppliers for a posteriori payment for goods and services. $\S 2$. The following are not equated as credit transactions: (Included by Resolution 19 of 2003) I - assumption of an obligation between legal entities of the same state, the Federal District, or the same municipality, under the terms of the definition contained in Art. 2, 
One might try to shoehorn the so-called fiscal maneuvers under the general expression other similar transactions. However, that classification is not valid, because the legal text, although containing a general clause, does not allow insertion of anything that does not have the nature of a credit transaction ${ }^{6}$.

Although this practice creates debts of a fiscal nature, the rule of Article 36 of the Fiscal Responsibility Law do not apply, since these debts do not result from a credit transaction, a bilateral contractual relationship calling for the financial institution to lend money or provide a credit facility in favor of the Treasury, to be repaid with interest. Instead, the debts that are created arise from default by the Treasury under a service provision agreement (for transfer of funds).

A credit transaction necessarily involves the transfer of ownership of the resources from the financial institution to the borrower, with recognition by the latter of a liability. When the borrower of a credit transaction is a governmental entity, because this involves an increase in the public debt, some requirements must be satisfied, such as previous budgetary authorization, through a specific law, with control exercised by the Senate in the case of the federal government.

In this conceptual universe, the rule on credit transactions cannot be expanded to fit any accounting liability of the public entity, such as the generation of debts to financial institutions because of default of contractual obligations, consisting of the failure to make timely transfers of funds for public banks to pay subsidies and benefits under social programs.

A credit transaction cannot be confused with the emergence of a credit resulting from a contractual breach, which obviously is not subject to the same legal restrictions. The federal government, like any other contractual party, must be held accountable for defaulting on its obligations assumed to the financial institutions with which it contracts, even when it is the controller of these institutions.

numeral I, of this Resolution; (Included by Resolution 19 of 2003) II - installment payment of existing debts to nonfinancial institutions, provided this does not imply an increase in the net consolidated debt. (Included by Resolution 19 of 2003).

6 As stated by Régis Fernandes de Oliveira in commenting on Article 36 of the LRF: "The law prohibits credit transactions. Nothing more. Hence, there is no impediment to renegotiating debts with the INSS [National Social Security Institute] or debts of the FGTS [Guarantee Fund for Time of Service]. Credit transactions are defined in Art. 29, numeral III, of the Law and do not include any debt settlements or novation that the federative entities seek to obtain. They involve taxes (or contributions) and there is no contractual act. They result from the legal obligations for their payment, so in the case of default, the governments are forbidden to engage in any bargaining to renegotiate the debt. The contrary solution would be absurd, in particular because it would fall foul of the very notion of the freedom of behavior of legal entities. The law is totally clear in vetoing excessive indebtedness, to the point of making the federative entity insolvent." 
Thus, the crucial point of the question is that the mere advance of amounts by public banks to provide cash flow under service provision agreements between the federal government and public banks, without the contracting of any credit transaction, is not subject to the legal rules on credit transactions, in particular the rule contained in Art. 36 of the Fiscal Responsibility Law.

If this were not so, it would be impossible for the federal government to contract public banks to perform any service, because a risk would always be present of default of obligations, generating a credit in favor of the bank, which would be interpreted as legally forbidden. By this reasoning, to avoid the risk of breaking the law, the federal government would only be able to contract private banks to render services, which is absurd and demonstrates the mistaken hermeneutics behind the claim that such a debt to the bank is a credit transaction.

But even if this were not the case, the fiscal maneuvers could not be classified under any of the cases of malfeasance in office of the President of the Republic for violation of the budget law, as defined in Article 85, VI, of the Constitution. The cases of malfeasance in office are typified in the Constitution and cannot be expanded, either by ordinary lawmakers or judges.

The Brazilian Constitution attributes to infra-constitutional lawmakers the task off establishing substantive and procedural laws, except in the areas reserved for the Constitution itself. Therefore, for example, an ordinary law cannot regulate procedures or competencies of the Senate or Chamber of Deputies in any way contrary to the Constitution. Likewise, the scope of impeachable offenses cannot be stretched to include crimes other than those defined in Article 85.

Based on this strict constitutional typology, it must be recognized that since the Constitution only contemplates classifying violation of the budget law as malfeasance in office, then violation of Articles 35 to 37 of the Fiscal Responsibility Law cannot be construed as malfeasance. It should be mentioned that not even Law $1,079 / 1950^{8}$, with

7 This is intuitive, as astutely argued by José Afonso da Silva: "All these crimes will be defined in specific laws, which shall establish the rules on procedure and judgment (Art. 85, sole paragraph, already existing in Law 1,079/50), naturally respecting the typical figures and substantive matters circumscribed in the numerals of Art. 85." It is thus possible to state that the crimes involving malfeasance in office are subject, in the Brazilian legal system, to a regime of strict constitutional typology, so that makers of ordinary law can only specify or detail practices that fall within the scope of the constitutional types." (emphasis added)

8 Art. 10. The following are crimes of malfeasance against the budget law: 6) to order or authorize the opening of a credit line in discordance with the limits established by the Federal Senate, without foundation in the budget law or in an allowed additional credit or without observance of a legal prescription; (Included by Law 10,028 of 2000); 7) to fail to promote or order in the form of the law the cancellation, amortization or constitution of a reserve to 
the wording given to it by Law 10,028/00 (to adapt it to the Fiscal Responsibility Law (LRF) by defining budgetary crimes), establishes violation of the LRF as cause for impeachment in its Article 4, VI. These are comprehensively listed in its Article 10.

The advance payment by public banks of obligations of the federal government, even if could be construed as a credit transaction (which, as seen, is not the case), would still not be an impeachable offense. These crimes involve violation of the Annual Budget Law ("LOA"), not the LRF. The LOA contains the rules on handling all the revenues and expenditures of the federal government. Malicious violations of its provisions can, in theory, be cause for impeachment of the President for malfeasance in office. In turn, the LRF contains general rules of financial law to orient the preparation, control and oversight of the LOA, but it contains no rules about revenues and expenses. Its violation is not constitutionally or legally typified as malfeasance in office.

Likewise, it is also not possible to classify the conduct in question under items 6 to 9 of Article 10 of the Impeachment Law (Law 1,079/50), since delayed transfer of resources to pay subsidies and benefits through public banks cannot be classified under any of the conducts defined in that law, as will now be explained:

First of all, item 6 of Article 10 of the Impeachment Law punishes opening of credit lines in discordance with the limits established by the Senate or without authorization in the LOA. As seen, the delayed transfer of funds by the federal government to public banks is contractual default, and the amounts must be paid regardless of being contemplated in the budget or subject to limits set by the Senate. The funds transferred go to pay for social programs, as required by the various laws establishing those programs, besides being included in the LOA. The payment of interest as a result of contractual default results from contracts approved by the Federal Audit Tribunal (TCU) and authorized by law. According to that legal framework, a transaction cannot be carried out without support in law or by the Senate. On the contrary, the transactions result from payments that the federal government is legally required to make, which rules out application of Article 10 of Law 1,079/50.

With respect to item 7 , as a consequence of what has already been demonstrated, there is no way to cogitate that measures need to

\footnotetext{
annul the effects of a credit transaction that oversteps a limit, condition or amount established in law; (Included by Law 10,028 of 2000); 8) to fail to promote or order the full settlement of a credit transaction due to advance of budgetary revenue, including the respective interest and other charges, by the end of the financial year; (Included by Law 10,028 of 2000); 9) to order or authorize, in discordance with the law, the realization of a credit transaction with any of the other entities of the Federation, including their entities of the indirect administration, even in the form of novation, refinancing or postponement of a previously contracted debt; (Included by Law 10,028 of 2000).
} 
be taken to annul the effects of the transactions, since they have legal support, as seen.

Regarding item 8, there was no credit transaction through advance of revenue, as defined in Article 38 of the LRF. Instead, there was only use of accounts to provide supplementary cash.

The mechanism also does not fit under Article 10, item 9, of Law $1,079 / 50$, which defines as malfeasance the opening of credit transactions by one entity of the Federation (one level of government, including a subentity of the indirect public administration) with another federative entity (another level of government or sub-entity thereof). This is a situation totally foreign to the transactions described in the finding of the TCU, the denunciation of the jurists in the impeachment motion or the decision of the president of the Chamber of Deputies to accept the motion, because the so-called fiscal maneuvers involve only the federal government and financial institutions controlled by it, not state and municipal governments or their entities of the indirect administration.

Therefore, it must be recognized that none of the conducts described in the finding of the Federal Audit Tribunal (TCU), in the impeachment motion or the decision of the president of the Chamber to accept it, fall under Article 10 of Law 1,079/50.

Furthermore, even if the "fiscal maneuvers" described by those who support impeachment and accepted by the president of the Chamber of Deputies could be construed as violation of the budget law, the fact is those actions occurred in 2014, during the first term of President Dilma Rousseff. Since the president of the Chamber decided to accept only the accusations involving actions in 2015, under the correct interpretation that according to Article 86, $\S 4$, of the Constitution, the President of the Republic can only be impeached for actions during the current term (which started on January 1, 2015), the fiscal maneuvers described in the finding of the TCU recommending rejection of the executive accounts for 2014 cannot serve as the basis for the impeachment motion.

It is true that the petition for impeachment drafted by the jurists and the decision by the president of the Chamber mention in passing that the fiscal shenanigans continued in 2015. But it is obvious that mere references without any specific identification of the acts in that year cannot support any imputation of malfeasance in office, especially because the finding of the TCU, on which the conclusions of the president of the Chamber were based, make no reference to situations in 2015. For these reasons, there is no legal support for the impeachment motion with respect to the fiscal maneuvers.

\subsection{The opening of supplementary credits by executive decree}

Besides the fiscal maneuvers, another ground for the impeachment 
motion that was accepted by the president of the Chamber involves four decrees (not numbered) issued on June 27, 2015 and two others, also not numbered, issued on August 20, 2015, to provide supplementary credits, supposedly without legal authorization. ${ }^{9}$

The purpose of supplementary credits is to increase budget appropriations to cover certain expenses already included in the Annual Budget Law (LOA), because of shortfalls of revenue in relation to that originally contemplated. That procedure is routine in government affairs, since the budget is only a forecast of how much will be spent in light of how much revenue is received during the year. The forecasts almost always need to be revised during budget execution, because of both fluctuations in revenue and extraordinary spending needs. For this reason, Congress, at the time of enacting the LOA, authorizes the opening of supplementary credits by presidential decree, within the limits and conditions imposed on the exercise of this prerogative.

The allegation that the issuance of those decrees was illegal and thus constitutes malfeasance in office is based on Article 4 of Law 12,952/14, the Annual Budget Law for 2014 (LOA/14), which made the opening of supplementary credits conditional on meeting the primary surplus target set in Law 12,919/13, the Budget Guidelines Law for 2014 (LDO/14). In the view of the supporters of impeachment, that primary surplus had not been attained when the decrees were issued.

9 Decree of July 27, 2015: opens in the Federal Fiscal Budget, in favor of various bodies of the Executive Branch, a supplementary credit of $\mathrm{R} \$ 29,922,832.00$, to reinforce appropriations contained in the current Budget Law. Decree of July 27, 2015: opens in the Federal Fiscal Budget, in favor of various bodies of the Executive Branch, Federal Financial Charges and Refinancing of the Federal Bond Debt, a supplementary credit of R\$ 36,759,382,520.00, to reinforce appropriations contained in the current Budget Law. Decree of July 27, 2015: opens in the Federal Fiscal Budget and Federal Social Security Budget, in favor of the Ministries of Education, Social Security, Employment and Labor, and Culture, a supplementary credit of $\mathrm{R} \$ 1,701,389,028.00$, to reinforce appropriations contained in the current Budget Law. Decree of July 27, 2015: opens in the Federal Fiscal Budget and Federal Social Security Budget, in favor of various bodies of the Legislative, Judicial and Executive Branches, the Federal Public Defender's Office, the Federal Prosecution Service and for Transfers to the States, Federal District and Municipalities, a supplementary credit of R\$ 1,629,519,495.00, to reinforce appropriations contained in the current Budget Law. Decree of August 20, 2015: opens in the Federal Fiscal Budget, in favor of the Ministries of Agriculture. Stockbreeding and Supply, Finance and Cities and in Federal Financial Charges, a supplementary credit of $\mathrm{R} \$ 55,237,582,569.00$, to reinforce appropriations contained in the current Budget Law. Decree of August 20, 2015: opens in the Federal Fiscal Budget, in favor of the Ministries dos Transportation, National Integration and Cities and the Secretariats of Civil Aviation and Ports, a supplementary credit of $\mathrm{R} \$ 1,201,641,285.00$, to reinforce appropriations contained in the current Budget Law (cited in SERRANO, Pedro Estevam Alves Pinto. Complementary Legal Opinion, available at http://blogdotarso.com/2015/12/06/jurista-pedro-serrano-emite-parecercontra-o-impeachment-de-dilma/, consulted on December 7, 2015. 
The great flaw in that argument is that it is improper to claim that limits in the LOA for 2014 were exceeded by supplementary credits opened in relation to the budget for 2015 .

The analysis must focus on whether the opening of supplementary credits in 2015 violated the current budget law. That law (Law 13,115/15, or LOA/15), was only approved in April 2015, and contained text in its Article 4 similar to that in the same article of the LOA/14, conditioning the opening of supplementary credits to meeting the primary surplus target set for 2015, as had been defined in Law 13,080/15 (LDO/15).

In reality, what happened in both 2014 and 2015 was that the primary result targets had to be revised during the year because of revenue shortfalls in relation to what had been forecast, caused by the economic crisis. These revisions were formally authorized by law.

Those alterations in spending needs result from the characteristic of the budget directives law, which is enacted the year before that of budget execution, and generally is based on a different economic scenario than what holds sway at the time of budget execution. In short, lawmakers cannot predict next year's economic scenario with sufficient accuracy, and hence the tax revenue for the following year will often be lower than envisioned. This is the natural fruit of what has been called the risk society ${ }^{10}$, and subjects all budget forecasting to the possibility of adjustment to reality, as pointed out by Ricardo Lobo Torres $^{11}$ regarding the difficulties of meeting primary surplus targets due to the unpredictability that characterizes modern times:

"One of the great challenges of this turn of the century is to achieve financial stability and budgetary balance through long-range policies. Two systems point the way in this respect: that of the United States and that of New Zealand.(...)

The reception of the New Zealand model by Brazil, through the Fiscal Responsibility Law, was based on the financial policy of Fernando Henrique Cardoso's administration, which sought to eliminate the primary deficit, without impairing payment of interest to artificially support the Real.(...)

In any event, the objective of achieving monetary stabilization and a primary surplus was attained

10 About unpredictability in modern society, see BECK, Ulrich. Risk Society: Towards a New Modernity. New Delhi, Sage, 1986.

11 TORRES, Ricardo Lobo. Vol. V - O Orçamento na Constituição. 3rd ed. Rio de Janeiro: Renovar, 2008, pp. 447-449. 
with the LRF. (...)

What characterizes the risk society is the ambivalence embedded in its rules and policies, which simultaneously bring advantages and disadvantages to citizens. From the standpoint of the law, as noted by Luhmann, the future risks are unforeseeable and against them the legal categories of validity and efficacy start to wane. The LRF does not escape this ambivalence. It exhibits, in the effort to eliminate fiscal risks, aspects of extraordinary relevance in the control of budget management and rigor in the balancing of the public accounts, while at the same time it has economic and political grounds of doubtful efficacy and difficult adaptation to our constitutional structure."

From this unpredictability that impairs adjusting budget planning to our constitutional system comes the possibility of changing the primary fiscal target established by the budget directives law, as discussed by Régis Fernandes de Oliveira ${ }^{12}$ :

"There can be no doubt that the Multi-Year Plan can be altered at any time, in light of new circumstances. Since it is intended to cover a period of four years in Brazilian law while the empirical world is malleable, and thus can undergo alterations, it cannot be rigid. Times change, circumstances change, situations change. (...)

The same thing applies to the Budget Directives Law. When an imperious circumstance arises, the possibility of changes that will benefit the population cannot be discarded. The end is not the law itself, nor is the law an end in itself. What matters is society, and when obstacles arise, nothing is more reasonable than to think of altering the law." (emphasis added)

As everyone knows, during 2014 and 2015, Brazil's economic situation deteriorated, due to both internal causes, such as the political crisis, and international ones, such as the declining value of the country's

12 OLIVEIRA, Régis Fernandes. Curso de Direito Financeiro, p. 362. 
commodities. This led to a shortfall in tax revenue, justifying alteration of the primary fiscal target determined by the Budget Directives Laws (LDOs) for 2014 and 2015.

The automatic consequence of these legislative alterations was legitimacy to open supplementary credits by decree during the year, since the condition set forth in Article 4 of the LOA/15 for that measure (compliance with the primary target) was satisfied. In other words, because of the amendment of the Budget Directives Law (LDO), the opening of supplementary credits by decree was authorized, as set forth in the Annual Budget Law (LOA).

Therefore, the limits for funding supplementary credits established in the budget law were revised before the end of the fiscal year. The question to be posed is whether it was legally possible to allow those supplementary credits based on the new limits before approval of the law that altered the primary result target.

In an ideal world, it would obviously be advisable to wait for Congress to approve the law to alter the primary target before using the authorization contained in it to open supplementary credits. However, it is necessary to recognize the "outlines" of the dynamic adopted by lawmakers themselves in establishing an uncertain future event as a "condition" for that authorization, one whose occurrence or not can only be ascertained at the end of the fiscal year in course.

In this scenario, the operative mechanism is a condition subsequent instead of a condition precedent. Were it necessary for a condition precedent to be satisfied to authorize opening supplementary credits by decree, this authorization would never occur within the current fiscal year, which would make that mechanism for authorization granted upon the enactment of the Annual Budget Law in practice futile.

However, with a condition subsequent, it is possible to open supplementary credits by decree any time up to the condition's confirmation. In other words, the extra credits can be authorized until it is verified in the current year that the target will not be met, which normally is only possible at the end of the year. With the legislative alteration of the target, the condition is also altered, which produces effects regarding its verification at the end of the year.

According to the reasoning used by the president of the Chamber, the partial picture revealed by the bimonthly primary revenue and expenditure reports can already be used to identify satisfaction of the condition subsequent, if from them it is possible to verify that the target will not be met at the end of the year, automatically canceling the authorization to open supplementary credits by decree.

However, this reasoning is faulty, because those reports, issued according to Article 165, $\S 3$, of the Constitution and also Article 52 of the LRF, do not have such powerful effects. Instead, their objective, in 
name of the principle of transparency, is only to reveal the evolution of fiscal execution at two-month intervals during the year.

Their disclosure, although it can reveal a potential difficulty of attaining the fiscal goal at the end of the year, prodding the executive branch to take the measures necessary to resolve the mismatch between the forecast revenues and expenditures and those actually realized, does not allow a definitive conclusion that the target will not be met. In short, only after the end of the year is it possible to ascertain whether or not the primary fiscal result was achieved. And in the case at hand here, enactment of Law 13,199/15 assured the target would be met that year. The bill that led to that law, proposed by the executive branch, was based on the realization that, in light of the bimonthly reports, the forecasts in the LDO were not compatible with the performance of the Brazilian economy in the first half of 2015.

Were the contrary argument to prevail - that the bimonthly reports already indicated interim failure to meet the fiscal target, thus implying confirmation of the condition subsequent and cancellation of authorization to open supplementary credits - the executive branch would be left without instruments to react to the effects of the economic crisis. This inability to assure supplementary credits to pay entitlements under legally established social programs when revenue falls short of the forecast, thus jeopardizing the fiscal target, would make the country's financial and budgetary life unmanageable. Logically, that reasoning must be rejected because it would lead to fiscal irresponsibility.

It should be noted that with the alteration of the primary surplus by Law 13,199/15, the Congress found a solution, and altered the limit for authorizing supplementary credits also set by it. This validation of acts practiced beforehand, to adjust the condition subsequent regarding supplementary credits to the new economic reality, is fully within congressional powers.

Were this not the case, economic difficulties arising after enactment of the Budget Directives Law could never be effectively faced by the government. Instead, the shortage of revenues would leave it in a conundrum of revising priorities between meeting the primary fiscal target or honoring the expenditures established in the budget. In any event, the decision to relax the target or cut spending rests with the Congress, and this was preserved in the case at hand.

The situation of binding the executive branch to a surplus target set in another scenario, without the legislative branch having the ability to consider the matter in light of the new reality, would mean subordinating the Brazilian state to the payment of interest to the financial sector, something that obviously is not a decision that can be automatically extracted from the current legal system. In short, the Congress must have the chance to give a different solution to the problem. 
As seen, the primary target was altered in 2014, with the approval of Law 12,952/14, which modified Law 12,919/13 (LDO/14), and again in 2015, since the Congress approved, on the same day the president of the Chamber accepted the impeachment motion, Bill of Law $05 / 15$, which became Law $13,199 / 15$, reducing the primary target set in Law 13,080/15 (LDO/15).

In this normative context, there is no way to speak of opening of supplementary credits without legal authorization in 2014. With respect to 2015, after enactment of Law 13,199/15, the same observation applies. Moreover, it is not possible before the end of the year to state whether or not the decrees that opened supplementary credits overstepped the limits authorized in the budget for that purpose, since that authorization is subject to a condition subsequent whose satisfaction can only be ascertained at the end of the year.

Finally, it should be clarified that the fact the decrees were not given numbers is legally irrelevant. This is a common practice long used for executive orders on specific matters (as opposed to normative acts), as is the case of decrees to authorize supplementary budget credits.

Therefore, the issuance of decrees in 2015 to open supplementary credits was previously authorized by Article 4 of Law 13,115/15, that year's budget law, according to the primary target set forth in Law $13,080 / 15$ (LDO/15), with the wording given to it by Law 13,199/15. Hence, there can be no legitimate claim that the supplementary credits were opened without legal authorization.

Finally, there is no way to claim that the issuance of those decrees can be subject to Article 10, items 2 and 3, of Law 1,079/5013, which penalizes the conduct of exceeding or carrying over budget appropriations without legal authorization.

\subsection{The jurisprudence from the federal audit tribunal, the manifestations of congress and legal security}

The Prior Opinion from the TCU in TC Proceeding no. 005.335/2015-9 has a technical and legal character based on interpretation of facts and rules of financial law. It recommended rejection of the executive accounts for 2014, in particular regarding the points that gave rise to the acceptance of the impeachment motion (the fiscal maneuvers and opening of supplementary credits by decree), even though not referring to conduct during the current presidential term, so that these matters cannot be considered by Congress with respect to impeachment (as recognized by the president of the Chamber

13 “Art. 10. The following are crimes of malfeasance against the budgetary law: 2 - Exceeding or carrying over budgeted appropriations without legal authorization; 3 - Canceling budget appropriations;" 
in accepting the motion).

However, its interpretations are the fruit of one vision of the phenomena under examination, and just like interpretations by a police authority regarding criminal matters and revenue authorities regarding tax matters, they can be subject to other views, starting with Congress, which is entrusted with approving or rejecting the executive branch's accounts, pursuant to Article 49, IX, of the Constitution.

Specifically with respect to the two points mentioned above, the Federal Audit Tribunal itself has adopted a different interpretation in other cases. Indeed, in many previous cases, when faced with the same facts and the same legal rules, it adopted a different position, urging approval of the accounts.

The contracts between the federal government and public banks containing clauses authorizing the banks to act as conduits for payment of benefits have been approved by the TCU for more than 14 years, without any caveat regarding their legitimacy. During this entire period (since 2001), this mechanism has been used by the federal government (as well as the state and municipal governments), without any finding by the TCU (or the equivalent state and municipal audit tribunals) of violation of the rules of financial law. On the contrary, the report by the TCU in TC Proceeding no. 021.643/2014-8, in item $396^{14}$, recognized that the negative balances in the transfer accounts are not characterized as credit transactions, and has no influence on the primary result.

In the same sense, TCU-Plenary Decision no. 992/2015, in item 26 , also recognized the impossibility of classifying the mechanism as a credit transaction:

"However, it is necessary to observe, in fact, that it would not be reasonable to classify as credit transactions mere brief delays in transferring funds from the Treasury, contemplated and with contractually stipulated conditions, as in the case of social programs paid through Caixa Econômica Federal. (emphasis added).

As seen, although the so-called fiscal maneuvers are a longstanding procedure in budget management, until 2014 the TCU had expressed no concerns. On the contrary, it expressly allowed the practice.

14 " 396 . The delay in transferring funds did not produce any impact on the fiscal result, since the liabilities generated by the referred delays are recorded in the fiscal statistics by the Economic Department of the Central Bank, meaning to say that the respective primary deficit variations are adequately reflected when determining the fiscal result. Nor were they sufficient, in the interpretation of the audit team, to configure realization of a credit transaction between the federal government and the financial institutions." (emphasis added) 
In relation to the retroactive effects of approval of an alteration of the primary target, the same phenomenon of a shift in jurisprudence occurred. During 2009, it became clear that the fiscal target established in the LDO could not be met (as happened in 2014 and 2015). So, the executive branch sent a bill to Congress to change the target, but even before it was approved on October 9, 2009 (becoming Law 12,053/09), the government started using the new target to raise the budget appropriation limits. That practice was subsequently analyzed by the TCU and considered to be legitimate, as stated on pages 80 and 82 of the Previous Report and Opinion on the Federal Executive Accounts for 2009. ${ }^{15}$

In the conclusion of that report, on p. 409, the rapporteur of the case, Judge Raimundo Carreiro, considered the procedures followed by the executive branch to be correct, without any reservations or recommendations for changes in this respect:

"The analysis leads to the conclusion that the Federal Executive Branch observed the fundamental principles of accounting applied to the public administration, that the balance sheets adequately demonstrate the financial, budgetary and equity positions of the Federal Government on December 31, 2009, and that the parameters and limits defined in the Fiscal Responsibility Law were respected, reservation only made for the following aspects:" (emphasis added)

The same thing happened in 2010, when the primary target established in the Budget Directives Law for 2010 was found to be unattainable, prompting the executive branch to send a bill to Congress that was only approved on December 30, 2010 (Law 12,377/10). The

15 "On October 13, 2009, Art. 3 of the LDO-2009 was altered, substituting the deduction from the primary surplus related to the Pilot Project for Public Investments (PPI) by the expenditures realized under the Growth Acceleration Program (PAC), increasing the amount subject to deduction to $\mathrm{R} \$ 28.5$ billion. (...) At the end of the second two-month period, a complete evaluation was conducted of all the primary revenue and obligatory expenditure items of the Federal Government. The Executive Branch sent a bill of law to Congress (Bill 15 of 2009) which proposed reduction of the target to $1.4 \%$ of GDP for the Central Government and $0.20 \%$ of GDP for Government Companies, with further proposal to exclude the Petrobras Group from the calculation of the public-sector fiscal result. Those parameters started to be applied in the twice-monthly reappraisals even before approval by Congress, which only occurred on October 9, 2009, with enactment of Law 12,053/2009. After analyzing the new projection of the items at the end of the year, combined with the alteration of the fiscal targets proposed to Congress by the Executive Branch, it turned out to be possible to expand the limits of budget appropriations and financial movements by $\mathrm{R} \$ 9.1$ billion in relation to the previous evaluation, under the terms of Art. 9, $\S 1$, of the LRF." (emphasis added) 
alteration of the target legitimized the cancellation of appropriations and opening of supplementary credits that year. The procedure was again approved by the TCU without reservations or recommendations in this respect, ${ }^{16}$ through adoption of the report of the rapporteur, Judge Aroldo Cedraz. ${ }^{17}$

Furthermore, Congress approved the accounts for 2009 and 2010, as urged by the TCU, even though decrees were issued before revision of the fiscal target that legitimized the opening of supplementary credits by decree. In 2014, the Previous Report and Opinion on the Federal Executive Accounts ${ }^{18}$ was diametrically opposed to its previous jurisprudence, urging rejection of the accounts due to the alleged existence of flagrant disrespect for the constitutional principle of legality (Article 37, main section), the budgetary rules in effect and the presuppositions of planning,

16 As stated in the Previous Report and Opinion on the Federal Executive Accounts for 2010, on pp. 73 and 74: "Subsequently, through Las 12,377/2010, the fiscal result target was reduced to $3.10 \%$ of GDP, of that $2.15 \%$ for the Fiscal Budget and Social Security Budget, and $0.95 \%$ for the Overall Expenditures Program. The nominal target for the period was also altered, which thenceforth allowed deficits of $1.28 \%$ of GDP, as was the net indebtedness target, which increased from R\$ 795.977 billion to R\$ 983.263 billion, corresponding to $27.72 \%$ of GDP. (....) According to the table under analysis, the Federal Government produced a primary fiscal surplus of $2.14 \%$ of GDP, a percentage below the target of $2.15 \%$ set for 2010 . In absolute terms, considering GPD for 2010 of R $\$ 3.675$ trillion as disclosed by the IBGE, the primary result target to be attained was R\$ 79.011 billion. Therefore, the surplus result of R\$78.100 billion was about R\$ 911 million below the target. However, taking into consideration Art. 3 of the Budget Directives Law for 2010 (Law 12,017/2009), that difference can be overcome by deduction from the target of the corresponding realization, under the "cash" concept, of PAC expenditures."

17 As stated on p. 477: "The analysis leads to the conclusion that the Federal Executive Branch observed the fundamental principles of accounting applied to the public administration, that the balance sheets adequately demonstrate the financial, budgetary and equity positions of the Federal Government on December 31, 2010, and that the parameters and limits of the Fiscal Responsibility Law were respected, reservation made for the aspects indicated in this Report." (emphasis added)

18 The Previous Report and Opinion on the Federal Executive Accounts for 2014 stated, on p. 180: "It cannot be alleged that the supervening enactment of Law 13,053/2014, which altered the fiscal target in the LDO for 2014 on December 15, 2014, overcame the requirement to limit the budgetary and financial execution. The reason is that the situation indicating the fiscal target would not be met stressed in the Report on Evaluation of Compliance with Fiscal Targets for the 2nd Four Months of 2014 thenceforth imposed adoption of the provision of Art. 9 of the LRF, combined with Art. 51 of the LDO for 2014. That fact characterizes a situation of omission, in light of estimates that already incorporated the effects of the bill of law sent to Congress, a bill that was at that time bereft of any legal force. This situation constituted flagrant disrespect for the constitutional principle of legality enshrined in Article 37, main section, of the Constitution, the budgetary rules in effect and the presuppositions of planning, transparency and responsible fiscal management to prevent deviations able to alter the balance of the public accounts, under the terms of Article 1, § 1, of Complementary Law 101/2000." 
transparency and responsible fiscal management to prevent deviations able to alter the balance of the public accounts, under the terms of Article $1, \S 1$, of Complementary Law 101/2000.

As can be seen, the position of the TCU changed totally on a key point of the matter: the influence of the supervening legal modification of the primary target in relation to the practice of acts associated with budget management in the period between when the bill was sent to Congress and was approved. Until 2014, the practice of acting immediately instead of waiting for Congress to approve the bill was accepted, without any reservation or recommendation. This gave all those involved in budget execution certainty that the practice was accepted by the TCU. To the general surprise, it took a diametrically opposed position in 2014.

Obviously, oversight authorities can change their interpretation of the rules, in name of better control over the public accounts. That jurisprudential evolution is also common by the judicial courts.

However, the new legal criteria utilized in interpreting facts and rules should only produce effects for the future, so as to respect legal security and protect legitimate confidence, as stressed by Ricardo Ribeiro Lodi ${ }^{19}$, based on the writings of Klaus Tipke, Garcia Novoa, Robert Alexy and Hartmut Maurer:

The State must guarantee legal security to citizens regarding the effects of the acts practiced by them according to the orientation given not only by the executive branch, but also the judicial branch, especially with respect to the jurisprudence from the highest courts. Although the effect of a judicial decision is, as a rule, ${ }^{20}$ binding on only the parties to the case, the judicial orientation, once established in steady and consolidated form, winds up instilling an element of trust in citizens, ${ }^{21}$ who act according to the judicial orientation given by the precedent. ${ }^{22}$

19 RIBEIRO, Ricardo Lodi. A Segurança Jurídica do Contribuinte - Legalidade, Não Surpresa e Proteção à Confiança Legítima. Rio de Janeiro: Lumen Juris, 2008, pp. 239-240.

20 Except in cased decided involving concentrated control of constitutionality, as per Art. 27 of Law 9,868/99, and those where the position of the Supreme Court has been consolidated with issuance of a binding precedent, under the terms of Art. 103-A of the Constitution, included by Constitutional Amendment 45/04.

21 TIPKE, Klaus. La retroactividad en Derecho Tributario, p. 354; GARCIA NOVOA, César. La Devolución de Ingresos Tributarios Indebidos. Madrid: Marcial Pons, 1993, p. 205.

22 For Alexy, the binding force of precedents derives from three reasons: predictability, protection of trust and equal treatment of similar cases. (ALEXY, Robert. La Institucionalización de la Justicia. Tranlated by José Antonio Seoane, Eduardo Roberto Sodero and Pablo Rodríguez. 
On the other hand, the principle of protection of legitimate trust cannot prevent the jurisprudence of the courts from evolving according to new social facts and the development of the science of the law. But it is correct to assume that, in name of legal security, large jurisprudential ruptures only can produce effects in the future. ${ }^{23}$

In the case here, the decisions of the TCU and of Congress in judging the executive accounts, and more so of the Chamber of Deputies and the Senate regarding the admissibility and judgment of the impeachment process, must also be based on protection of legitimate trust. And when the presidential mandate is in play, it is essential not only to observe legal security under an individual prism, but also to consider democracy and respect for the will of the majority of voters expressed in elections.

Also for these reasons associated with legal security and democracy, the so-called fiscal maneuvers and the approval of supplementary credits according to the new fiscal target cannot be utilized to configure malfeasance in office of the President of the Republic.

\subsection{As financial nonconformities and typification of malfeasance in office}

Even if the conclusions of the Federal Audit Tribunal for rejection of the executive accounts were correct, which is only mentioned for argument's sake, there was no nonconformity of the presidential actions with the budget law to configure the malfeasance in office established in one of the items of Article 10 of Law 1,079/50. As stated by Ricardo Lobo Torres $^{24}$, the principles associated with budget control must be weighed against others that govern the actions of the President of the Republic:

"The principle of balance has high relevance on the matter of the budget, since it permits weighing all the other legal principles pertaining to the ways and means law, both the underlying principles and those related to the ideas of freedom, justice and legal security. The principle of balance leads to choosing the principles that must prevail in light of urgent social interests, both at the moment of preparing the

Granada: Comares, 2005, p. 85).

23 MAURER, Hartmut. Elementos de Direito Administrativo Alemão, p. 81.

24 TORRES, Ricardo Lobo. Vol. V - O Orçamento na Constituição. 3rd ed. Rio de Janeiro: Renovar, 2008, p. 202. 
budget and allocating funds and during the phase of discretionary management and control of budget execution.

In this respect, a certain flexibility in execution of the budget in relation to the original forecast is justified, to assure continuity of public policies, notably those aimed at the neediest people in a scenario of economic difficulty. This applies both to the executive and legislative branches, as observed by Régis Fernandes de Oliveira ${ }^{25}$ :

"It is important to attribute to agents instruments for flexibility in the use of public funds, to allow them to redirect allocations, facilitate tenders, alter expenditures, etc., all to attain the desired goal.

Obviously all must be subject to hierarchical control or it will be the exclusive responsibility of those tasked with managing the funds allotted to the program. What does not make sense is to attribute a purpose, appropriate funds and then restrict the actions of the agents. Trust must be placed in them to properly manage the available resources, while at the same time, not forgoing the control mechanisms.

In line with this flexibility, it is legitimate for the President of the Republic to seek alternatives, in the face of economic difficulties, to protect the continuity of social programs through mechanisms already used by past administrations through procedures approved by the Federal Audit Tribunal. One of these mechanisms is the opening of supplementary credits, which is justified because it is more important to continue paying social benefits than to generate fiscal surpluses. This has always been recognized as legitimate by the TCU and Congress. Otherwise, Law 13,199/15 would not have been approved.

Therefore, these practices cannot be classified as budgetary malfeasance, because the risks of not using them in 2015 would have placed severe constraints on the public finances. Furthermore, malfeasance in office requires malice aforethought to violate the budget law, which in the present case did not occur, because the President reasonably relied on the precedents from the TCU and Congress allowing those practices.

25 OLIVEIRA, Regis Fernandes de. Curso de direito financeiro. 7th ed. São Paulo: Revista dos Tribunais. 2015, p. 685. 
A president cannot be accused of malfeasance in office for making decisions to try to overcome difficult problems. Without the advance payment of social benefits by the public banks, would those obligations to the public have been met? The answer is no: without modification of the primary target and reallocation of budget rubrics with opening of supplementary credits, a series of legally authorized and required expenditures would likely not have been paid. The decisions on these matters are entrusted to the President of the Republic together with Congress, based on the best judgment of the balance of risks at the time. Wrong or right from a political or economic standpoint, the measures had legal support from precedents from the TCU and Congress.

Furthermore, the decision by the president of the Chamber did not refer to any indication of personal benefit or favoritism of other parties in the conduct imputed to the President of the Republic, which also impedes characterization as malfeasance in office.

Precaution must be taken regarding the admission and judgment of the impeachment motion, so as not to annul the popular manifestation of the Brazilian people at the polls due to an accounting technicality, common in managing the country's budget.

In light of all the observations above, we can conclude that:

a) The so-called fiscal maneuvers, defined as the delay in transferring funds from the Treasury to public banks for payment of social benefits and entitlements, under a service provision arrangement between these institutions and the federal government, cannot be classified as credit transactions, so they are not forbidden by Article 36 of the LRF.

b) Violation of the LRF cannot be classified as an impeachable offense for violation of a budget law, because neither the Constitution of 1988 nor Law 1,079/50 (in both cases as amended) contains any provision that violation of the Fiscal Responsibility Law can be construed as malfeasance in office.

c) Article 10 of Law 1,079/50 does not describe any conduct that can cover the facts narrated in the Opinion of the Federal Audit Tribunal (TCU), the impeachment complaint or the decision of the president of the Chamber to accept it.

d) It is not possible to prosecute the President of the Republic for acts supposedly committed before the start of her current term, on January 1, 2015. Therefore, the acts described in the Prior Opinion from the TCU, issued as part of TC Proceeding no. $005.335 / 2015-9$, urging rejection of the executive accounts 
for 2014, do not serve to support an impeachment proceeding.

e) The opening of supplementary credits was authorized by Article 4 of the Annual Budget Law for 2015, as amended regarding the primary target by Law $13,199 / 15$, so there can be no claim that these credits were supplied without legal support.

f) The procedures imputed to President Dilma Rousseff in 2015 are supported by the jurisprudence from the TCU established up to 2014, and the interpretations were approved by Congress.

g) The modification of the criteria for interpretation of financial laws and the facts by the TCU and Congress can only have future effects, under pain of violating protection of legitimate trust, legal security and democracy.

h) Not just any violation of the budget law can be grounds for impeachment. The budgetary principles must be weighed against others, such as the need for continuity of public services, and the risks of government bankruptcy.

i) There are no legal reasons for admissibility of the impeachment motion by the president of the Chamber of Deputies.

\section{THE ABUSES AND INJURIES TO THE CONSTITUTION COMMITTED BY BRAZILIAN COURTS: THE JUDICIALIZATION OF POLITICS AND "ACTIVIST JUDGES"}

The intense demand and evident growth of mechanisms for "control" and "punishment" in the political world, headed by the judicial branch under the aegis of judicial activism, under the argument of fighting ethical deviations of political agents, has in reality become "judicialization of politics", a proactive stance by the courts in performing their functions that improperly interferes in elections and the political actions of the other branches of government.

That reality has a negative repercussion on judicial activity, by creating the dangerous possibility of politicization of the judicial function, as recognized by the Portuguese professor Boaventura de Souza Santos in asserting that "the judicialization of politics leads to the politicization of justice."

A derivation of this way of acting, particularly present in the pre-electoral period, is what can be called the "judicialization of the electoral and political process", consisting of the excessive interference 
of the judiciary in political activity.

This causes an undesirable state of ongoing political control by the courts, which should not be protagonists in the political process by improperly interfering in the democratic playing field.

Instead, the courts should only assure the legality and serenity of the natural political conflicts of the democratic process, because political activity should not be constrained, only modulated.

This situation is aggravated by the unconscious psychological factors, which are part of the personality of any person and influence the formation of critical judgment. When these factors prevail, notably ideological leanings, the judge's impartiality is impaired, regardless of his or her will. In this sense, knowledge of the subconscious psychological factors of the judge is essential for the judge to control these inclinations and with this preserve the maximum impartiality at the time of judging.

A related trend of concern is the intense mediatization of the natural disputatiousness of human relations. Sectors of the judicial branch, besides acting as protagonists of the political process at any price, including committing serious constitutional violations, have been swayed by media manifestations of popular commotion and the perceived need to satisfy the anxieties of a society controlled by the dictates of the communications media, spokesmen of the elites in Brazil, with the objective of purging from public life people seen as undesirable and unworthy of political office.

Even in the twenty-first century, an attempt exits to implement a "punitive society", fruit of a transnational political project that resorts to coercive legislation and police tactics to disperse or repress any opposition to the power of corporations, suppressing political dissent for the purpose of solidifying the neoliberal project. The fascism that emerges today is not political, but rather social, and coexists with a weak democracy, to paraphrase Boaventura de Souza Santos.

In this respect, it is important to outline the relations between the modern reality of criminalization of politicians in Brazil, representatives of the people, elected by popular vote, and the effects of a progressive weakening of fundamental rights, notably observed in the constant and terrifying relaxation of constitutional rights. This is the case of suppression of political rights, which are a subtype of human rights, as well as the sapping of fundamental rights to protecting citizens from criminal prosecution.

The effects of punitivism in electoral legislation, for example, relying on worrying theoretical support, are highly evident today. The spreading criminalization of politicians is most often presented in veiled form, as if this did not in reality involve a problem of criminality. An ascending role can be observed of penal policy in politics, 
oriented toward imprisonment, punishment and extirpation of constitutional rights through interpretive flexibility resulting from the phenomenon of pre-comprehension of the interpreter. Here mention should be made of the important teachings for constitutional hermeneutics of Konrad Hesse, in his work Escritos de Derecho Constitucional.

In this sense, any reflection that contests the criminological credo of the media discourse must be ignored or hidden from the public at large, the telespectators. ${ }^{26}$

Foucault, in Discipline and Punish: The Birth of the Prison, teaches that the threat of prison is a versatile force that needs to be given a leading place in the study of contemporary power. For this reason, the idea of consolidation of discipline and punishment is found in various governmental entities, including in the motivation of members of the judicial branch who embrace the "judicialization of politics"

A parody can be made between the Foucaltian "discipline and punish" and "judge and punish", critical of the action of the judicial branch in the administration of the "punitive machinery of the state", with emphasis, as stated by Foucault, on the role of the prison in the society of discipline and control.

A distinction exists between judicial activism and judicialization of politics. The constitutional interpretation has been gradually providing more space, in Brazil as well as other countries, for judicial activism and consequently broader interpretations of the Constitution, as asserted by Pier Paolo Portinaro ${ }^{27}$.

This situation of greater engagement of judges through judicial activism unleashes consequences for the constitutional role of the division of powers and in the materialization of the principle of legal security, raising concerns regarding the guidelines of hermeneutic processes.

Our objective is not to criticize judicial activism, but to find objective boundaries, limits to the actions of the judicial branch, because in the final analysis "who controls the controllers?"28 if this dimension does not have appropriate parameters.

A critical analysis is needed of judicial activism and its distortion into judicialization of politics in constitutional matters. In this respect, it is enlightening to study the dichotomy seen between moderate political positivism, along the lines of Norberto Bobbio, and the post-positivist musings of these days, which in reality are anti-positivist. In the line

26 Op.Cit., p.6.

27 In his text "Beyond the Rule of Law: Judges' Tyranny or Lawyers' Anarchy?" in Pietro Costa and Daniel Zolo (Org), The Rule of Law History, Theory and Criticism. Springer Netherlands, 2007.

28 A classic question posed by Professor Celso Lafer on the matter, making reference to the work of Mireille Delmas-Marty, La Refondation des Pouvoirs, Paris: Seuil, 2007, in particular pp.38, 41-43 and 67. 
advocating the moderate positivism of Bobbio, supported by the modern theory of interpretation, one can find Emilio Betti and HansGeorg Gadamer, who methodologically allow the interaction between principles and rules.

The analysis of this problemimplies considering the constitutional division of powers, as already stated, and the need to discern between the moment of the legislation and the moment of its application by the courts, eliminating the theses that defend a judicial activism that confers an elastic and subjective competence on the judge-interpreter, for the purpose of clarifying the mens legis of the tenets inserted in the Brazilian Constitution. The courts these days are stretching the interpretation far beyond what the Constitution establishes, at times contradicting its tenets. ${ }^{29}$

On the contrary, value must be given to legal guarantism, an expression of the principle of legality, in matters of constitutional interpretation, because this is isolated from political value judgments, expressed in interpretations swayed by ideology and the axiological heritage of the judge at the moment of deciding.

Besides this, one cannot disregard the unconscious psychological factors and the necessary observance of the personal axiological background of the judge in constructing the decision.

For this challenge, we use as a paradigm the doctrine of Konrad Hesse regarding the pre-comprehension of the interpreter. According to this framing, there are no "aseptic" interpretations, not influenced by axiological of psychological elements, and political ideology is probably one of the strongest elements compromising the interpretation.

Obviously, all legal rules require an interpretation. Lawmakers present an "ascetic language". For this reason, the judge, in applying the law, has the task of giving life to the rules. In analyzing the problem of constitutional hermeneutics, three guideposts are fundamental for the proper comprehension of the rules. They are the text itself (the corpus of the rules), the interpreter (and consequently his or her personal heritage), and the interpretation.

One must also consider that constitutional interpretation has a particular profile, because of its ideological content. Therefore, the central activity of applying the rule rests in the interpretation, with the interpreter being responsible for the real content of the rule.

Since the problem of constitutional interpretation is essentially a question of a political nature, because it seeks to correlate changes in scenario with guaranteed political rights, it is necessary to limit and coordinate the exercise of this political power, this being the

29 Norberto Bobbio, Contribuición a la Teoria de Derecho, org. Alfonso Ruiz Miguel, Valencia: Fernando Torres Ed., 1980, "Formalismo Juridico e Formalismo Etico", p.105-117. 
fundamental reason for having constitutional texts ${ }^{30}$. Meirelles Teixeira says it is important that:"the Constitution be known not only in its letter, but also its spirit." 31

In this sense, the importance of constitutional interpretation is fundamental, given the open, vague and multiple meanings of many of its rules ${ }^{32}$. Besides this, through interpretation it is possible to know the "intimate meanings of a Constitution." "33

With respect to constitutional hermeneutics, the American doctrine customarily distinguishes interpretation from construction.

For constitutional law, then, the importance of interpretation is fundamental because of the multiple meanings that can be assigned to its rules ${ }^{34}$. On this matter, Ferrara believes that the interpreter's mission is to search for the real content of the rule, since "the law does not contain unnecessary words."

In this sense, the object of the interpretation is the will of the law, autonomous, not the will of the framers, much less the applier of the rule. This analysis allows a certain degree of leeway for the judge to interpret, but without inventing rules, taking the place of the framers. Kelsen states, in turn, that the judge many not create rules, but can create rights.

In various European countries in recent times it has been possible to observe the trajectory of constitutional jurisdictions, notably in the controversies produced by the so-called "interpretative verdicts" 35 .

On this matter, Konrad Hesse makes an important contribution with the formulation of his famous thesis The Normative Force of the Constitution. The renowned author, professor and judge of the Federal Constitutional Court of Germany, a disciple of Smend, demonstrated his intention to succeed in the academic attempt to offer a balance able to avoid sacrificing the normative dimension of the Constitution in face of the contingencies of real life.

Hesse stresses, among the conditions that enable reaching a balance that preserves the normative dimension, the will of the Constitution, meaning an alternative in face of the mere will of power or formal and abstract normativity bereft of the volitive element. $\mathrm{He}$ further points out that the so-called will of the Constitution is based on three ideas: the conviction of the need for an objective and stable

30 Celso Ribeiro Bastos, Interpretação e Aplicabilidade das Normas Constitucionais, p. 16.

31 Meirelles Teixeira, Curso de Direito Constitucional, p. 266.

32 Paulo Ricardo Schier, Filtragem Constitucional - construindo uma nova dogmática jurídica, p. 113.

33 Meirelles Teixeira, Curso de Direito Constitucional, p. 266.

34 Paulo Ricardo Schier, Filtragem Constitucional - construindo uma nova dogmática jurídica, p. 113.

35 These are verdicts that determine or express, depending on the sense in which these are employed, constitutionality or unconstitutionality. 
legal order, as a guarantee against arbitrariness and excesses of power in general; the belief in the importance of an order whose normative value does not depend exclusively on rationality; and the importance of acts of human will directed to the realization of the Constitution ${ }^{36}$.

Hesse's contributions are of great help in the task of attaining a correct focus regarding constitutional interpretation. Nor does that process lack concrete and objective conditions from the historical framework to delineate the context of legitimacy in which constitutional legality operates, i.e., constitutional hermeneutics, far from being exhausted in the mere logical subjection or conceptual formulation, imposes the firm will of the interpreter with the purpose of realizing the constitutional objectives. ${ }^{37}$

Hans-Georg Gadamer and Emilio Betti try specifically to detect this common universe, that of the intersection. They seek the meaning of the projection of the main factors that connote the distinct interpretive processes in the constitutional universe as well as the consequences of the main hermeneutical theories in this respect.

Today, the hermeneutics of interpretation is understood as a process of comprehension of meaning, including understanding of the text with the role played by the interpreter and his or her personal background in the composition and construction of the interpretation ${ }^{38}$. It is necessary to invoke, in understanding the meaning of the words that integrate the text, the context in which they were written. Besides the question of analyzing the context, modern hermeneutics also deals with the problem of the interpreter's pre-comprehension, which Gadamer calls the "interpreter's prejudices". 39

For Gadamer, the comprehension of a text is similar to a dialog, which can only occur between people who speak the same language, or at least know the signs of the language in question. ${ }^{40}$

In this sense, Pérez Luño stresses the importance of the tradition that resides in the community about the experience of each person in composing the common language, permitting inter-subjective communication in the community engaging in dialog. ${ }^{41}$

In the universe of constitutional methodology, hermeneutics has meant new attention to the pre-comprehensive structure of interpretation of the law combined with its historical conditions. ${ }^{42}$ Therefore, jurists

36 Ibidem

37 Op. cit., p. 254.

38 Maria Garcia, for example.

39 Antônio E. Pérez Luño, Derechos Humanos, Estado de Derecho y Constitución, p. 264.

40 Ibidem.

41 The comprehension of a text is not possible without considering the historical connection between the subject and the object of the interpretation.

42 Antônio E. Pérez Luño, Derechos Humanos, Estado de Derecho y Constitución, p. 264. 
cannot interpret rules without being aware of the concrete situation in which they are inserted. In this form, the constitutional interpreter acts as a mediator between the normative text as promulgated and the demands of the present situation, engaging in a practical-normative activity that establishes a continuity between the moment of promulgation and the moment of application. ${ }^{43}$

Therefore it must be concluded that the materialization of the constitutional rule cannot be bereft of analysis of the pre-comprehension of the interpreter, based on his or her experiences knowledge and prejudices resulting from the historical conjuncture. Likewise, the task of materialization and comprehension of the constitutional rule is impossible without considering the real problems. ${ }^{44}$

Scientific purity requires excluding any question about the legitimacy and the justice of laws ${ }^{45}$. On the other hand, the law is ideological to the extent it conceals the sense of the structural relations established among subjects, for the purpose of reproducing the mechanisms of social hegemony. ${ }^{46}$

Therefore, Luís Roberto Barroso argues that "the belief is false that the law is a politically neutral domain," because jurists only manage to formulate a "discourse that conceals the functions and functioning of the law in society." Therefore, the so-called critical theory of the law aims to "revise the traditional concept of the legal science, demonstrating how starting from a discourse organized in name of the truth and objectivity, it is possible to deviate from the socio-political conflicts that are present in the individual relations that can be harmonized by the law." ${ }^{\prime \prime}$

Joseph William Singer, writing about the American version of the critical legal studies movements, states that:

"The law is not apolitical and objective: lawyers, judges and scholars make highly controversial

43 Op. cit., p. 265.

44 Ibidem.

45 André Franco Montoro cites Del Vecchio to affirm that "the notion of fairness is the cornerstone of the legal edifice." Therefore, the law does not exist without the notion of justice. 46 Luís Alberto Warat, A produção crítica do saber jurídico, for example.

47 Ibidem. Luís Roberto Barroso states in this respect:

"The critical theory of the law is eminently interdisciplinary. It is realized through a discourse of intersection, involving multiple bodies of knowledge: those accumulated by legal thinking over the centuries and those of other fields, such as linguistics, sociology, political economy, social psychology, anthropology, history and psychoanalysis. From an even more philosophical and profound perspective, it exhibits the influence of the philosophers of the so-called Neo-Marxist school of Frankfurt, which includes Max Horkheimer, Herbert Marcuse and Theodor Adorno. Also in the picture are the works on hermeneutics developed by Jürgen Habermas, Hans-Georg Gadamer and Paul Ricoeur, on the role of the interpreter and the indeterminacy of texts." 
political choices, but use the ideology of legal reasoning to make our institutions appear natural and our rules neutral." 48

If the legal interpretation is a practical activity that seeks to achieve certain goals, the ideological horizon is a substantial element of any hermeneutical process, consciously or not ${ }^{49}$. This matter is not recent. The ideological function of interpretation and its consequences have been the focus of constant reflections.

But what we intend to demonstrate on this point is that the alternative use of the law does not necessarily imply a progressive legal posture.

The Constitution, as expressed by Hesse, is not only an expression. of being (Sein), but also an expression. of duty (Sollen), since it "seeks to impress order and conformity on political and social reality." ${ }^{50}$ Therefore, for Hesse the activity of interpretation consists of expressing the constitutionally correct result, through a rational and controllable procedure, also rationally grounded and controllable, that enables the creation of a relative certainty and legal predictability ${ }^{51}$.

The legal world is being overwhelmed in the criminal sphere by the conservative credo of locking up miscreants en masse, while in the political sphere the equivalent is the penalty of ineligibility to hold office, particularly affecting the representatives of the less favored classes, amounting to their "banishment from the political world", condemning them to political invisibility, the cruelest punishment that can be meted out to a politician. ${ }^{52}$

A significant portion of the communications media has been increasingly relying on revelations of "misdeeds" obtained from dubious sources to discredit distasteful candidates, with no concern for the truth of the accusations.

These fallacious news stories, whose dissemination does not fall under the constitutional right of expression, are particularly destructive when they come on the eve of the election, not giving the accused candidate a chance to defend him or herself.

48 Luís Roberto Barroso, Interpretação e Aplicação da Constituição, p. 268, citing Joseph William Singer, "The player and the cards: nihilism and legal theory", in Yale Law Journal, passim.

49 According to Antônio E. Pérez Luño, this theme was addressed at a congress held in Catania, in May 1972, about "The Alternative Use of the Law".

50 Ibid.

51 Paulo Ricardo Schier, "Filtragem Constitucional - Construindo uma nova dogmática jurídica", p. 113, in Konrad Hesse, Escritos de Derecho Constitucional, p. 104.

52 As previously mentioned, Complementary Law 135/2010, which amended the Statute of Political Ineligibility (Complementary Law 64/1990), established eight years of ineligibility to hold elected office, a period that can be considered, in most cases, a political death penalty. 
This is not an argument to limit the freedom of information, nor the constitutional right to criticize. Experienced politicians know this is part of the democratic game and bear with resignation and restraint the personal bruises of public life and electoral disputes. Our protest is against cases that extrapolate the exercise of the democratic freedom of expression and the constitutional right to criticize.

Hence, there is a need for limits on the revelation of information that is known to be untrue or constitutionally protected by the right of privacy, something that unfortunately is becoming ever more common in our society.

The press has attained huge autonomy in contemporary society, to the point of exercising strong social power, often making citizens hostages to rather than receivers of information. Therefore, it is necessary to defend not just the freedom of the press, but also the freedom from the press.

The so-called "fourth power", to paraphrase Norberto Bobbio in his work Dicionário de Política, is composed of information media that play a determining function in the politicization of public opinion. In constitutional democracies, the press has the ability to exercise critical control over the three governmental powers: legislative, executive and judicial.

Therefore, when a citizen goes to court to obtain redress for the publication of a lie or information protected by the constitutional right of privacy, this does not involve freedom of the press, but rather protection of civil rights.

On the one hand, society needs a press that is dignified, precise, honest, clear and objective. On the other hand, it is uncontestable that some "media barons", only worried about the profits to be had from sensationalism, in particular electoral sensationalism, confuse freedom of the press, constitutionally protected, with the "freedom to print", i.e., the possibility of publishing everything that is beneficial to them, whether from a political or economic standpoint.

The freedom of the press is not absolute or unlimited, because it does not extend to spreading untrue information, as specified in the constitutional text. Insisting that the press is totally free, without exceptions, does violence to the state of law.

It is no easy task to ascertain whether or not freedom of the press is exercised abusively. A good general framework can be gained from various opinions of Judge Nancy Andrighi ${ }^{53}$, such as the following one:

\section{"The freedom of information must pay heed to the duty of veracity, because disclosing false data}

53 She is a member of the Superior Tribunal de Justiça (STJ), the highest court for nonconstitutional matters, with responsibility for harmonizing interpretation of federal law by the state and regional federal courts of appeal. 
manipulates instead of forming public opinion."

Vital Moreira, in a monograph ${ }^{54}$, expresses various conceptions that aim to justify, in doctrine and dogma, the right of response, while warning about the insufficiency of a "unifunctional explanation", because the right of reply serves multiple functions: (a) the right to reply as "defense of the rights of personhood", (b) the right to reply as an "individual right to express an opinion", (c) the right to reply as an "instrument of informative pluralism", (d) the right to reply as a "duty of truth of the press"; and finally (e) the right to reply as "a form of "sui generis' sanction, or monetary compensation for slander."

The American Convention on Human Rights, better known as the "Pact of San Jose, Costa Rica", in its Article 14, recognizes that all persons who feel attacked by untrue of offensive information disseminated by the media have the right to reply and correction ${ }^{55}$.

However, it is rare for the media to give equal time to reply, instead trying to destroy the public careers of those who participate in the political universe, by omitting or distorting information when not spreading outright falsehoods.

In this respect, it is worth recalling the figure of Homo Sacer, developed in the work of Giorgio Agamben, an enigmatic figure brought from Roman criminal law, a person who is banned and may be killed by anybody but may not be sacrificed in a religious ritual.

That attitude has prompted a counter-reaction by defenders of the democratic credo, who advocate legality and dedicate their academic efforts to sustain the inexistence of "aseptic" interpretations, not influenced by axiological and psychological elements. In this respect, political ideology and interests are among the strongest elements of interpretation. In Brazil, that dichotomy is aggravated by the fact that the judgments of the Supreme Court are televised.

"Media prejudgments" are constant in Brazil. On one side, society needs a press that is dignified, honest, clear and objective, while

54 MOREIRA, Vital. O Direito de Resposta na Comunicação Social, item n. 2.6, 1994, Coimbra: Coimbra Editora, pp. 24-32.

55 "Article 14 - Right of Reply:

1. Anyone injured by inaccurate or offensive statements or ideas disseminated to the public in general by a legally regulated medium of communication has the right to reply or to make a correction using the same communications outlet, under such conditions as the law may establish.

2. The correction or reply shall not in any case remit other legal liabilities that may have been incurred.

3. For the effective protection of honor and reputation, every publisher, and every newspaper, motion picture, radio, and television company, shall have a person responsible who is not protected by immunities or special privileges. 
on the other some media barons are only interested in profiting from electoral sensationalism, confusing freedom of the press, constitutionally protected, with "freedom to print", the possibility of printing anything of interest to them, from a political standpoint, and mainly an economic one.

The injurious and politically manipulated acts of the communication media provoke public mockery of people, without giving them a fair chance to defend themselves, in effect denying them of the constitutional right of due legal process.

In face of the current situation of constant criminalization of politicians and progressive disrespect for fundamental rights, notably observed in the odious relaxation of constitutional rights, as in the case of suppression of political rights (a type of human rights), it is necessary to strengthen constitutional legality to maintain the democratic order.

There are many differences between judicial activism and judicialization of politics. In particular, the latter sins by invading the competencies of the other two branches of government, injuring the principle of representation and popular sovereignty and dangerously flirting with politicization of the courts.

Besides this, there is evidence of political bias of judges, as seen by their ideological verdicts, revealing the aspirations and desires of social classes in conflict. This absence of impartiality of judgments in the political-electoral universe is an ailment that can only be attenuated, but not banished, through multidisciplinary self-reflection by judges.

\section{The DANGer OF INSTITUTIONAL RUPTURE AND THE DEFENSE OF DEMOCRACY}

Brazilian democracy is very fragile at this moment, requiring proactive defense of the Constitution and the rule of law. Powerful internal and external forces, upset with the social and economic policies followed, have started to execute a process to destabilize the country, with the clear objective to recover the power they used to hold in the country.

This destabilization process has arrived at a crucial moment, because the democratic freedoms and fundamental rights assured by the Constitution of 1988 are under threat from the serious institutional crisis that has been created.

This is a serious step backwards from the democratic legitimacy and normality that was reestablished after the more than two decades of military dictatorship and human rights violations that victimized Brazil until 1985.

This defense of democracy does not mean those who have committed transgressions should not be held accountable. But in name of punishing wrongdoers, the Brazilian Constitution cannot be torn up; the fundamental rights of citizens cannot be left by the wayside 
and replaced by guidelines imposed by elites, notably those defeated democratically in recent national elections in which the principle of the rule of law was strictly observed. In particular, the institutional rupture cannot be permitted of removing a chief executive from power in name of conducts of other people, not only those forming her support base (her own party and those of the broad governing coalition), but also her adversaries, many of whom are also being investigated, although protected by the nation's television networks, which flagrantly manipulate information and even present information that is demonstrably false in their pyrotechnic efforts.

For that reason, many intellectuals, of all parties and political ideologies, including noted adversaries of the governing coalition, have begun to protest against the impeachment drive, not only in academic and cultural institutions, but also in the streets, in defense of the Constitution and Brazilian democracy.

However, stronger vigilance is necessary, because powerful groups are working behind the scenes to stir up the "masses" with incitements of hate, tying to create violence to justify repression. Brazilian institutions, still relatively solid, need to rise to the occasion and play a decisive role in defending democracy. This is especially true the Supreme Court, which needs to be aware of the imminent danger of legal disorder and breach of the legal hierarchy, evils provoked by the excesses committed by some members of the bench, who appear to be committed to the demands of political groups, including disrespecting the Judgeship Law, which forbids political militancy by judges. Some have gone so far as posting in social networks their own photographs taken at political protests against defendants they will soon be called on to judge.

For these reasons, those who want to preserve Brazilian democracy need to make a herculean effort to overcome the danger of breaching the democratic system, including countering the propaganda disseminated by some extreme conservative sectors that even want closure of Congress and return to dictatorship.

Against this backdrop of discord caused by the protests for and against impeachment, marked by intolerance and lack of legal and political enlightenment, the essence of the legal question involving impeachment has largely been overlooked, namely the fundamental difference between presidentialism and parliamentarianism.

In presidentialism, the figures of the head of government and chief of state are unified in the same person, while in parliamentarianism these functions are exercised by different people.

The head of government in parliamentarianism exercises functions equivalent to those of the president in setting policy and administration of government, while the chief of state in most cases 
basically has ceremonial duties.

More importantly for the discussion here, parliamentarianism has the mechanism of the no-confidence vote, by which the prime minster can be removed just by losing the confidence of the parliament. Therefore, if a grave crisis or other reason erodes lawmakers' support, they can remove the head of government and replace him or her with someone else (chosen depending on the rules of the country in question).

In this case, when the president is found guilty of an impeachable crime, as opposed to mere political discontent, he or she is removed and replaced by the vice president, while the members of the legislature keep their seats.

So, popular discontent over economic policies and/or performance, or loss of majority support in the legislature, does not serve as reason for impeachment. In parliamentarianism, many causes can lead to a no-confidence vote, but in presidentialism the rules of the game are different. When an attempt to remove the president is based on accusations not involving malfeasance in office, then that effort can be described as a coup attempt.

In Brazil, the impeachable crimes are those comprehensively set forth in the Constitution and the Impeachment Law (Law 1,079/50), without leeway for expansive interpretation or reasoning by analogy. Therefore, a vote in Congress to impeach the President of the Republic without proof of the occurrence of malfeasance in office would be unconstitutional. As a logical corollary, the Supreme Court has the duty, as guardian of the Constitution, to nullify any impeachment motion accepted by the Chamber of Deputies and/or approved by the Senate in a formal guilty verdict, based on conduct other than defined as an impeachable crime.

This question has largely been ignored by the media and by public discussion during this incredible and torturous impeachment process against President Dilma Rousseff. As demonstrated, she has done nothing that can be described as an impeachable offense, either in the Constitution or the Impeachment Law.

Hence, the Supreme Court has the constitutional duty to invalidate the impeachment motion now under consideration in the Chamber of Deputies, due to the absence of the substantive requirements for acceptance of the request.

Both the jurisprudence from the Supreme Court and the Impeachment Law and Constitution make it clear that the President can only be removed for criminal malfeasance in office. As any other crime, impeachable crimes must be interpreted literally. In the matter of criminal prosecution, there is no room for in malam partem analogy (to the detriment of the accused).

This does not mean that an impeachment request does not have 
political content as well. But above all it is a legal procedure and must be treated with the necessary rigor, especially by strict observance of the constitutional dictates.

No evidence has been presented that the President was aware of any illegal acts, and (deliberately and maliciously) failed to intervene, much less that she ordered such acts. The mechanism of strict liability (regardless of gross negligence or intent) does not exist in criminal law as it does in some civil matters.

In the case now ongoing, only violation of rules in the budget law, as narrowly and comprehensively typified in Law 1,079/50 as crimes of malfeasance, can support the impeachment motion.

Congressional discontent, giving rise to "hermeneutical alchemy", is not enough to configure malfeasance in office, so that the impeachment drive as framed now can only be described as an attempted coup d'état.

Obviously, the judgment of merit regarding whether or not the President committed a crime classified as impeachable rests with the Senate. But this does not mean that in Brazil's democratic system it is possible for Congress to redefine what is and is not an impeachable offense, just by "political will". Therefore, without causing a flagrant rupture of the democratic order, the Senate cannot vote to remove the President for acts that are not impeachable, nor can the Chamber of Deputies vote to approve the impeachment motion and send the accusation to the Senate for judgment.

As the guardian of the Constitution, the Supreme Court has the duty to prevent the Chamber of Deputies from voting on the impeachment motion, or to declare the nullity of any guilty verdict reached by the Senate, for lack of any impeachable crime. Otherwise, the impeachment mechanism will become equivalent to the noconfidence mechanism in parliamentary systems. The Supreme Court must guarantee the supremacy of the Constitution and the democratic state of law, by rejecting the idea of the Criminal Law of the Enemy (Feindstrafrecht) formulated by Günther Jakobs and preventing breach of the constitutionally imposed rules of the game, even though a good part of public opinion considers them execrable, to recall the denomination Homo Sacer of Giorgio Agambem.

The attempt to stretch the notion of malfeasance in office, including to disregard the time element for definition of the supposed infraction, reveals the intention to reduce the guarantees afforded to the President. While a move to impeach a president will naturally trigger a political crisis, the existence of a political crisis cannot be used as an expedient to remove the president. In Brazil this is only possible in 
conformity with the Constitution and federal laws. ${ }^{56}$

The issue of legality is at the heart of the democratic principle and must assure the existence of processes to judge the legal fitness to hold office without arbitrary "political trials", which can serve as instruments for overthrowing a legitimate government, a veiled coup d'état. The impeachment process must respect the right to a fair proceeding, satisfying the rule of law, due process of law ${ }^{57}$ and the international treaties to which Brazil is a signatory. These tenets are insurmountable obstacles to the current impeachment process.

\section{REFERENCES}

ALEXY, Robert. La Institucionalización de la Justicia. Tranlated by José Antonio Seoane, Eduardo Roberto Sodero and Pablo Rodríguez. Granada: Comares, 2005.

BARROSO, Luís Roberto. Interpretação e Aplicação da Constituição. $7^{\mathrm{a}}$ edição. São Paulo: Saraiva.

BASTOS, Celso Ribeiro Bastos. Hermenêutica e interpretação constitucional. São Paulo: Celso Bastos Editor, 1997.

BECK, Ulrich. Risk Society: Towards a New Modernity. New Delhi, Sage, 1986.

BOBBIO, Norberto. Contribuición a la Teoria de Derecho. Org. Alfonso Ruiz Miguel, Valencia: Fernando Torres Ed., 1980.

COSTA, Pietro \& ZOLO, Daniel (Org). The Rule of Law History, Theory and Criticism. Springer Netherlands, 2007.

FIGUEIREDO, Marcelo. Elementos do Estado. São Paulo: Editora Atlas, 2014.

LUÑO, Antônio E. Pérez. Derechos Humanos, Estado de Derecho y Constitución. Madrid: Editorial Tecnos.

MAURER, Hartmut. Elementos de Direito Administrativo Alemão. Porto Alegre: Editora Sérgio Fabris.

MIREILLE, Delmas-Marty. La Refondation des Pouvoirs, Paris: Seuil, 2007.

MOREIRA, Vital. O Direito de Resposta na Comunicação Social. Coimbra: Coimbra Editora, 1994.

OLIVEIRA, Regis Fernandes de. Curso de direito financeiro. 7th ed.

56 TAVARES, Juarez \& PRADO, Geraldo. O Direito Penal e o Processo Penal no Estado de Direito: análise de casos, Florianópolis: Empório do Direito, 2016, pp.30-31

57 Op. Cit, p.37. 
São Paulo: Revista dos Tribunais. 2015.

RIBEIRO, Ricardo Lodi. A Segurança Jurídica do Contribuinte Legalidade, Não Surpresa e Proteção à Confiança Legítima. Rio de Janeiro: Lumen Juris, 2008.

SCHIER, Paulo Ricardo. Filtragem Constitucional - construindo uma nova dogmática jurídica.

TAVARES, Juarez \& PRADO, Geraldo. O Direito Penal e o Processo Penal no Estado de Direito: análise de casos, Florianópolis: Empório do Direito, 2016.

TIBURI, Márcia. Olho de Vidro: a televisão e o estado de exceção da imagem. Rio de Janeiro: Record, 2011.

TIPKE, Klaus. La retroactividad en Derecho Tributario, p. 354; GARCIA NOVOA, César. La Devolución de Ingresos Tributarios Indebidos. Madrid: Marcial Pons, 1993.

TEIXEIRA, Meirelles. Curso de Direito Constitucional. $2^{\mathrm{a}}$ edição. Porto Alegre: Editora Conceito, 2011.

TORRES, Ricardo Lobo. Vol. V - O Orçamento na Constituição. 3rd ed. Rio de Janeiro: Renovar, 2008.

WARAT, Luís Alberto. A produção crítica do saber jurídico, in PLASTINO, Carlos Alberto et alii. Crítica do Direito e do Estado. Rio de Janeiro, Graal, 1984. 